\title{
Analysis of the current situation of the hotel sector in the face of the COVID-19 health crisis. Case: Machala-Ecuador
}

\section{Análisis de la situación actual del sector hotelero frente a la crisis sanitaria COVID-19. Caso: Machala-Ecuador}

Karina Salazar ${ }^{1}$, Samantha Serrano ${ }^{2}$, Melissa Calle ${ }^{3}$

\footnotetext{
'Egresado de la Carrera de Administración de Hotelería y Turismo, Facultad de Ciencias Empresariales, Universidad Técnica de Machala, Machala, Ecuador. ksalazar2@utmachala. edu.ec https://orcid.org/0000-0003-0402-3640

Egresado de la Carrera de Administración de Hotelería y Turismo, Facultad de Ciencias Empresariales, Universidad Técnica de Machala, Machala, Ecuador. sserrano1 Quutmachala. edu.ec https://orcid.org/0000-0003-0371-4909

${ }^{3}$ Doctora de Ciencias Administrativas, Facultad de Ciencias Empresariales, Universidad Técnica de Machala, Machala, Ecuador. mpcallequtmachala.edu.ec https://orcid.org/0000-0003-1615-0559
}

\section{ABSTRACT}

Currently the tourism sector faces one of the most notable economic crises in recent years; the health emergency of the Covid 19 virus has caused different changes in the tourist plant of a destination; That is why the present research aims to analyze the state that the hotel sector is going through, in order to contribute to decision-making in tourism activity and in the identification of the problems generated from the pandemic. The methodology used was descriptive with a mixed approach, it consisted of obtaining qualitative and quantitative data, in which an online questionnaire was applied that provided the results. Where, it was possible to show that the vast majority of hotels have had a decrease in customers than usual, which is reflected in economic losses. From this, the application of new strategies has allowed a reactivation of its commercial sector where the implementation of biosafety measures and marketing in the different digital platforms have been more applied to counteract the health crisis. It should be noted that the participation of entities based on the competences with the tourism sector has been essential for there to be a commercial reactivation in the face of the COVID-19 health crisis.

Keywords: tourism sector, hotel establishments, biosecurity measures, socioeconomic losses, Covid-19.

\section{RESUMEN}

En la actualidad el sector turístico enfrenta una de las crisis económicas más notables de los últimos años; la emergencia sanitaria del virus Covid 19 ha originado distintos cambios en la planta turística de un destino; es por esto que, la presente investigación tiene como objetivo el analizar el estado que está atravesando el sector hotelero, con el fin de aportar a la toma de decisiones en la actividad turística y en la identificación de los problemas generados a partir de la pandemia. La metodología empleada fue de tipo descriptiva con enfoque mixto, consistió en la obtención de los datos cualitativos y cuantitavos, en el cual se aplicó un cuestionario vía online que facilitó los resultados. En donde, se pudo evidenciar que en su gran mayoría los hoteles han tenido una disminución de clientes a lo habitual, lo cual se ve reflejado en las pérdidas económicas. A partir de ello, la aplicación de nuevas estrategias ha permitido una reactivación de su sector comercial en donde la implementación de medidas de bioseguridad y el marketing en las diferentes plataformas digitales, han sido de mayor aplicación para contrarrestar la crisis sanitaria. Cabe recalcar que la participación de las entidades en función de las competencias con el sector turístico ha sido indispensable para que exista una reactivación comercial frente a la crisis sanitaria COVID-19.

Palabras clave: sector turístico, establecimientos hoteleros, medidas de bioseguridad, pérdidas socioeconómicas, Covid-19. 


\section{INTRODUCTION}

Tourism activity worldwide is one of the main sources of economic resources that in turn generates sources of employment, social, and tourism development in each territory. In the past, tourism was a symbolic activity with only 25 million tourists in 1950, but the strengthening of this activity has been evolving year by year, as in 2000 , the number of tourists reached 678 million and in 2010, the number of tourists was 950 million. Nowadays, the UNWTO expects that the number of tourists exceeds 1.800 million by 2030 . Fundamentally this growth has driven that tourism can be considered as "One of the most remarkable economic and social phenomena of the 20th century" (UNWTO, 2016).

Currently, tourism has been strongly affected by the pandemic caused by the coronavirus, which has produced, in addition to human losses, a large number of economic, social, cultural, and environmental losses. Likewise, the virus has had a significant impact on the tourism sector; hence, the entire tourist industry has experienced various changes to face the health crisis. Therefore, in order to contribute positively to the consolidation of the sector, it is essential to study the best practices and measures that services providers have currently implemented to offer their tourist services and thus, guarantee the reactivation and strengthening of the local economy in the future.

Among the aforementioned losses are the lodging establishments, which have had to face this crisis during the sanitary emergency and, as a result, have been forced to implement new biosecurity measures that guarantee customer safety in order to continue consuming the different services they offer. In this manner, the different tourism service providers need to implement strategies that facilitate decision-making in the progress of this tourism activity.

On the other hand, in El Oro province, tourism service providers today have opted to apply biosecurity measures necessary to ensure customer safety. However, the economic losses they face continue to be significant due to the current reality. It represents a risk to the commercial life of the hotel sector. Based on this, it is important to analyze the current situation of this productive sector and thus, identify which strategies are being employed to reactivate the growth of the sector after facing the Covid 19 pandemic.

Against this background, the following research question has been proposed:
What is the current situation of the hotel sector in the face of the Covid-19 health crisis?

\section{THEORETICAL BASIS The hotel industry in the tourism sector}

At present, productive activities, both in commerce and services, generate economic development in different territories around the world. Tourism is one of those activities that produce large economic revenues, and the hotel sector plays a fundamental role in tourism activities (Orlandini, Paco , \& Torricos, 2019).

Globally, hotels represent an economic benefit that generates a better quality of life for the community, specifically for those who work in this sector. As it is well known, hotels must offer quality services based on the rules established by the individual who regulates the tourism activity (Calle, Lazo, \& Granados, 2018). It is essential to emphasize that the set of norms are based on international standards, and through them, the classification for each sector is established depending on the category, type, and subtype of the same.

In Ecuador, the mandatory standards for this lodging sector are established through the Tourist Accommodation Regulation No. 20150024-A (Mintur, 2016), and thus, it is determined a classification and its category, which is detailed in the following table:

Table 1. Classification and Category of tourist lodging establishments.

\begin{tabular}{|l|c|c|}
\hline CLASIFICATION & NOMENCLATURE & CATEGORY \\
\hline Hotel & H & 2 to 5 stars \\
\hline Hostel & HS & 1 to 3 stars \\
\hline Lodging & LG & 3 to 5 stars \\
\hline Tourist farm & TF & 3 to 5 stars \\
\hline Lodge & L & 3 to 5 stars \\
\hline Resort & RS & 4 to 5 stars \\
\hline Refuge & RF & Single category \\
\hline Tourist camp & TC & Single category \\
\hline Guesthouse & GH & Single category \\
\hline
\end{tabular}

Source: Tourist accommodation regulation (2016)

1 star: the hotels offer few services. 
2 stars: the hotels are in a good location and offer basic services.

3 stars: the hotels stand out for the comfort of their facilities.

4 stars : the hotels have great facilities such as swimming pools, gyms, restaurants, etc.

5 stars: the hotels stand out for offering luxurious services.

\section{Covid-19 pandemic and the tourism sector}

In the last year, the Coronavirus-19 pandemic has affected world economies, especially in Latin America, resulting in socioeconomic losses.

This reality has also been reflected in tourism since the Covid 19 pandemic affected significantly the tourism sector, which depends on the attraction of tourists or visitors. In fact, due to the lack of visitors, the tourism plant has suffered economic losses and has even generated instability in the sector, producing in some cases the commercial closure of tourism companies in the hotel sector.

On the other hand, one of the effects of the pandemic is the lack of liquidity that exists due to the absence of activity, which results in taking crucial decisions, including the most significant, the dismissal of personnel; all this as prevention against a definitive closure of the establishment (Huilcapi, Troya, \& Ocampo, 2020).

However, despite all the negative factors involved in these times of crisis, it has been possible to reactivate the economy and commercial activity of some of the tourism companies. It has depended on the management and strategies established by the public sector through governance as well as the private sector, which has generated strategies to innovate the provision of services and guarantee the biosafety standards. In that sense, the community labor of the public and private sectors is an ideal option for minimizing the negative impacts generated by this industry. Thus, the need for the participation of entities, the organization of their dependence, and internal communication in each of the tourism companies is fundamental for the economic recovery of this sector (Rodriguez \& Álvarez, 2016).

\section{Impact of the health crisis on the tourism sector}

The sanitary crisis generated by the Covid-19 virus has had a considerable impact on all productive sectors of the country; taking into account that the Covid-19 virus started on December 27, 2019, in Asia, explicitly in the Wuhan province. This virus has spread notably among human beings and countries worldwide, affecting the economy and generating strategies that contribute positively to minimize the impacts caused by the health crisis. (Alvarado \& Arévalo, 2020). At the same time, since the beginning of the pandemic, the productive and service sectors noticed great changes related to the transit of people that cause human and economic losses. As a result, each country was trying to prevent the spread of the virus and minimize the effects on the economy (Acosta, 2020).

On the other hand, at the beginning of 2019, the tourism sector in Ecuador had a remarkable influx of tourists increasing by $4 \%$, according to the database of the administrative registry of migration of the Ministry of Government (2020). In this manner, great expectations of increase were obtained in front of this activity; however, at the end of that year, tourism activity partially stopped in every corner of the country. For that reason, at the beginning of the year 2020, the UNWTO begins to expose high containment measures to alarm the authorities of the damage that the virus would cause to both people and the productive and service sectors. In this case, the tourism sector would be affected if it was not fully controlled. (World Tourism Organization, 2020).

With the reality that today all economic sectors must face, it is considered that the tourism activity is one of the elements that has obtained more negative impacts and from which, it could not recover quickly, taking into account that the different governmental and private entities currently propose measures to counteract such impacts, planning strategies that benefit decision making such as the biosecurity measures against Covid-19 exposed by the Ministry of Tourism (2020), being, in this case, the lodging establishments belonging to the tourism sector the ones that find themselves with fewer job vacancies due to the low influx of visitors in the destinations and therefore low guest demand (Cifuentes, 2020). 


\section{Biosecurity measures implemented during the Covid 19 health crisis in the hotel sector}

Currently, the entire tourism sector has been forced to implement biosecurity measures that guarantee the health of tourists, and the hotel sector is not the exception. This hotel market was previously one of the investment sectors with a high growth within a long commercial activity, being essential for the tourist plant of a destination, but nowadays, this industry has had a low influx of guests. That is why, in some of the destinations, people have opted to close their establishments, causing a significant decline in this sector (Gonzales, 2020). Based on that, biosecurity measures have been implemented as a rule so that hotel establishments can carry out their activities, thus contributing to their economic and social development.

In Machala city, all hotel establishments that are working must take into account the danger of contagion they are exposed when there are interactions between staff and guests. Therefore, the biosecurity measures for all the accommodation have been considered, including the new customer service strategies within all areas that complement the provision of services, in which measures against Covid 19 are implemented, such as continuous hand washing and disinfection, a physical distancing between staff and guests, protective equipment for staff and future guests, capacity building, medical control for staff that allows them to have a very professional performance and the necessary knowledge to identify the possible symptoms. Hence, they can take the appropriate measures to ensure the health and hygiene of others (MINTUR, 2020). In that sense, the hotel sector must take into account that that biosecurity measures for the customer will not only be a short-term protocol, but also a long-term one since the Covid 19 health crisis in this sector has a significant impact, which requires these companies to innovate and establish strategies to reactivate the industry, guarantee the safety of tourists and promote the strengthening of sustainable local development in the tourism sector.

\section{METHODOLOGY}

This research is framed under the domain: Social Development in the research line Sustainable Tourism, of the Te- chnical University of Machala, supported by the research project approved by resolution of the University Council No. 159-2020, with the theme "Analysis of supply and demand in the provision of tourism services in the city of Machala period 2020, which is subscribed in the research group El Oro Turístico GRP -018.

The research is descriptive since it allows emphasizing the analysis of the data collected with the theoretical discussion of the object of study. In addition, it is based on a mixed approach, with quantitative and qualitative methods, used to interpret the results through fieldwork.

Purpose of the study: Provision of tourism services in the hotel sector according to the barriers faced by their commercial activity due to the impact caused by the Covid 19 health crisis.

Participants: The participants of this study are integrated by the administrators or managers of hotel-type lodging establishments in Machala city, which are registered according to the Mintur 2020 cadastre, as detailed below:

Table 2: Lodging establishments in Machala city

\begin{tabular}{|l|c|}
\hline \multicolumn{2}{|c|}{$\begin{array}{c}\text { LODGING ESTABLISHMENTS IN MACHALA CITY } \\
\text { Classification: Hotel }\end{array}$} \\
\hline Category & 14 \\
\hline 2 stars & 6 \\
\hline 3 stars & 1 \\
\hline 4 stars & 1 \\
\hline 5 stars & $\mathbf{2 2}$ \\
\hline Total & \\
\hline
\end{tabular}

Source: Ministry of tourism (2020)

The survey technique was used to generate the descriptive research design, which seeks to collect data through a questionnaire previously designed and applied to the study population.

\section{Instruments to collect data: Surveys}

A form with 13 objective multiple-choice questions was designed with the purpose of collecting information rela- 
ted to the different losses generated by the sanitary crisis, the strategies applied for the economic reactivation, and the entities that continue working in this reality. The forms were shared through Google forms to the corresponding e-mail addresses of each hotel company, with a prior call for their knowledge.

\section{RESULTS}

According to the fieldwork, the results have been obtained regarding the current situation that the hotels of Machala city are facing, and with the biosecurity measures they are using, the individuals who have been continuously involved in the reactivation of their activities and the strategies implemented to counteract the health crisis.

Figure 1: Closing of the commercial activity

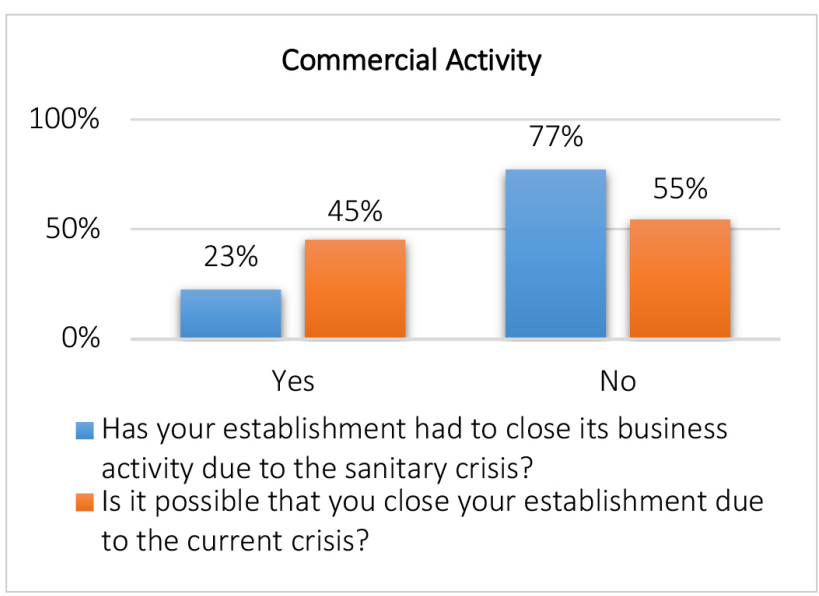

Source: Fieldwork 2020

Currently, the sanitary emergency has generated great negative impacts on the different economic sectors, both nationally and internationally. Hence, tourism activity is one of the most affected during this time due to the low influx of tourists that cause a decrease in demand in the tourist plant.

As a result, $23 \%$ of hotel establishments in Machala city have had to close their commercial activities due to the Covid 19 pandemic, while $45 \%$ state that there is a possibility of closing their commercial activities. This reality is worrying because $68 \%$ of the hotel sector has economic problems that affect commercial life. It is because the establishments belonging to the lodging sector, since the beginning of the health crisis, have been significantly affected in economic, social, and health areas; leaving their work activities for some time. Therefore, it is essential to analyze all the affected tourism sectors, in order to offer new useful strategies that promote the tourism activities and obtain benefits for the tourist service providers as well as society.

On the other hand, 77\% of the hotel-type lodging establishments are currently working and employing strategies to generate their reactivation in the market. However, Ortega (2020) states that the sanitary emergency worldwide has affected this sector potentially. Hence, the entrepreneurs have opted for another type of economic activity that generates the necessary income in order to promote their economy. Thus, in Machala City, the lodging sector is affected, but even so, some people are performing their functions to obtain economic, tourist, and social progress.

Figure 2: Does the hotel establishment have the annual operating license?

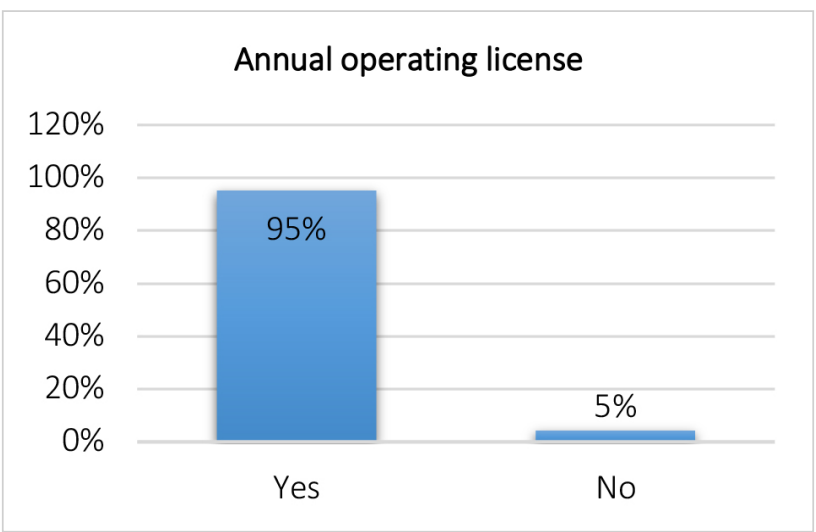

Source: Fieldwork 2020

$95 \%$ of hotel establishments have the annual operating license and $5 \%$ do not. It should be noted that this license is part of the fundamental requirements that all tourist-lodging establishments must meet in order to operate at the national level. Therefore, penalties will be applied for the absence of this mandatory requirement in the establishments according to Art. 55 of the General Regulations of the Tourism Law. According to Izquierdo, Andrade \& Lazo (2018) in their article on hotel quality, state that the annual operating licen- 
se is a requirement that certifies the establishments in order to receive guests with the required measures. In other words, it allows lodging establishments to improve their hotel quality, offering an adequate service for the tourist.

Figure 3: During the months when the country was under a state of emergency, how long was your hotel establishment out of operation?

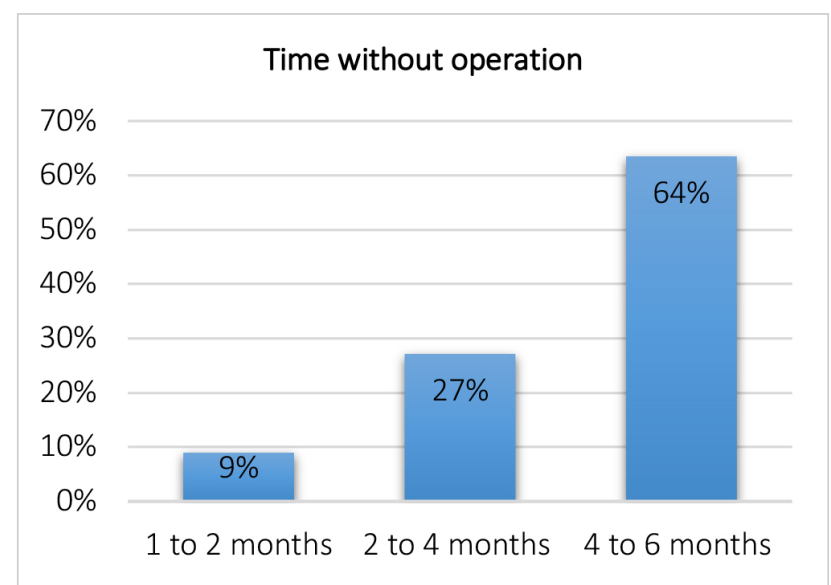

Source: Fieldwork 2020

Regarding the time that lodging establishments were out of operation due to the state of emergency in the country, $64 \%$ stated that they were out of service for an estimated 4 to 6 months, $27 \%$ stated 2 to 4 months and $9 \% 1$ to 2 months. It occurred due to the regulations adopted by the national government to safeguard the health of the personnel working in the establishments and the population in general.

That is why, Menchero (2020) in his published article on the tourist flows and Covid 19, manifests that the state of emergency in the tourism sector affects the people who offer their tourism services. It occurs because if people do not move from one place to another, it is not possible to make use of different establishments. Thus, within Machala city, some hotels stopped operating for periods of one to six months, causing economic losses and a reduction in the number of jobs. In other words, instability in the hotel sector. Therefore, nowadays, most of the hotels in the city have started commercial activities implementing biosecurity strategies and measures to promote the economic development of this sector.
Figure 4: Average number of guests per week

\section{Average number of guests per week}

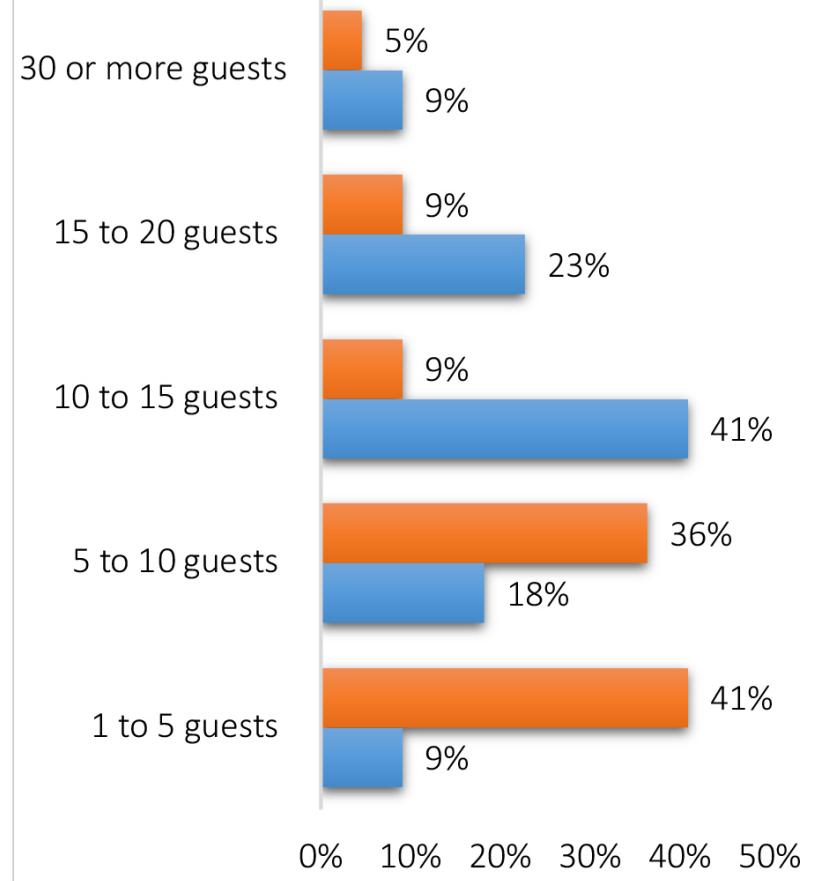

Currently, what is the average of guests in your establishment per week?

When the state of emergency began, what was the average of guests in your establishment per week?

Source: Fieldwork 2020

Among the average number of guests that the establishments had before the state of emergency in the country, $41 \%$ said they had 10 to 15 guests per week, $23 \%$ had 15 to 20 guests, $18 \%$ had 5 to 10 guests, while $9 \%$ said they received between 1 to 5 and others more than 30 guests. Therefore, it can be noted that previously the hotel sector had commercial stability, due to the loyalty of its customers and the average number of visits, which made use of the services through regular overnight stays. However, today the hotels that are offering their services have a notable decrease in the average number of guests, thus, $41 \%$ 
of hotels have 1 to 5 guests per week, $36 \%$ have 5 to 10 guests, $9 \%$ have 10 to 20 , and $5 \%$ have 30 or more guests.

This situation has caused instability in hotel companies, which has resulted in socioeconomic losses, reduction of jobs, and shorter working hours; measures that have been exposed in the Art. 47 of the Labor Code. Due to the current economic condition, hotel entrepreneurs are redesigning strategies that contribute positively to its development.

Lambogglia (2016) states in his article on the tourism growth in Ecuador that the influx of guests is the essential part for the constant growth of the tourist plant and to promote the economic, social, and tourism development in a destination. In this manner, the low demand of guests due to the Covid 19 health emergency has produced a decrease in employment and large economic losses in the hotel sector, affecting all tourism service providers.

Figure 5: Have you implemented biosecurity measures to serve guests? If yes, select which of the following measures:

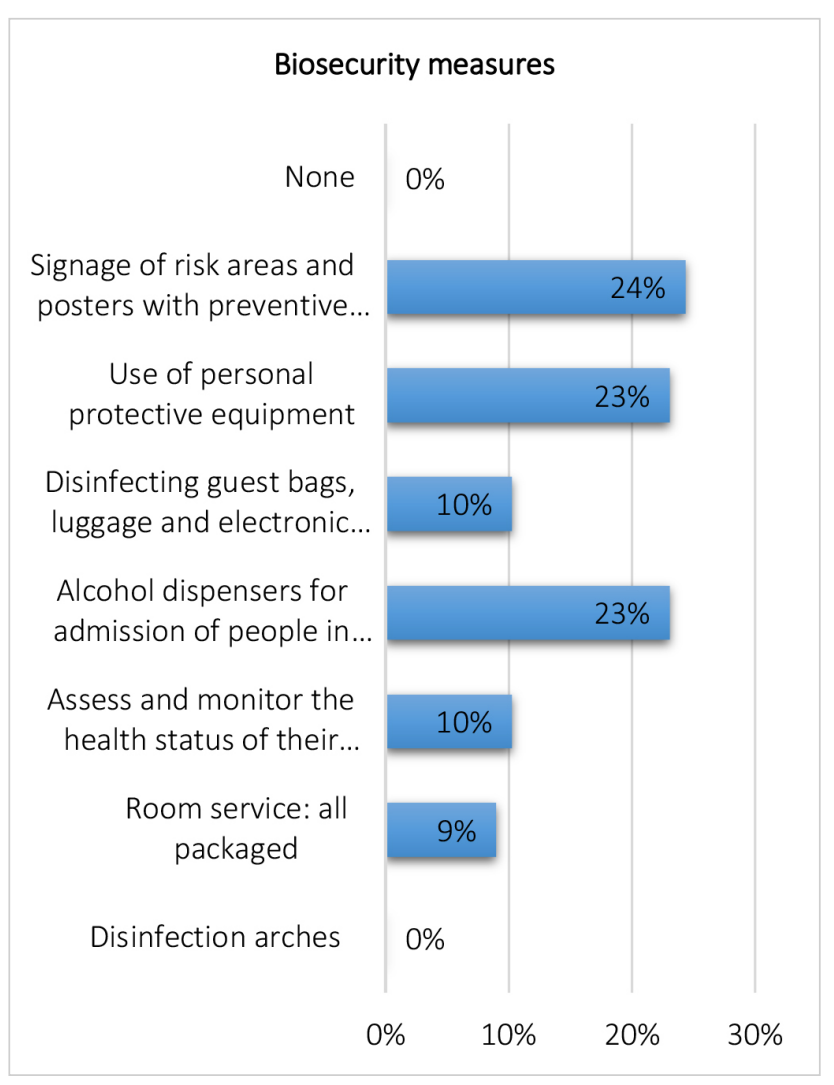

Source: Fieldwork 2020
In the biosecurity measures implemented to serve guests, $24 \%$ used signage of risk areas and posters of preventive advice, $23 \%$ use protective equipment for the staff, also they have disinfectant dispensers at the entrance and in strategic areas of the establishment, $10 \%$ constantly evaluate and monitor the health of employees and disinfect bags, luggage or electronic equipment of guests, while $9 \%$ perform the room service all packaged. These measures had been used by the hotel establishments to guarantee the health of staff and guests. Thus, they feel safe while they are using the tourist plant. As a result, each measure taken by the sector will minimize economic losses and achieve better tourism development.

Luzuriaga (2020) expresses in his article on post-pandemic reactivation vs. touristification, that biosecurity measures are mandatory for all tourism establishments, which offer their services to society. Considering that the Covid 19 virus is highly contagious, it is essential to provide an adequate function to the tourism activity by guaranteeing the health of the people and taking into account that this sector is a great source that promotes the economy of a destination.

Figure 6: Has your staff had any training on biosecurity measures for receiving guests once the state of emergency is over?

\section{Training biosecurity measures}

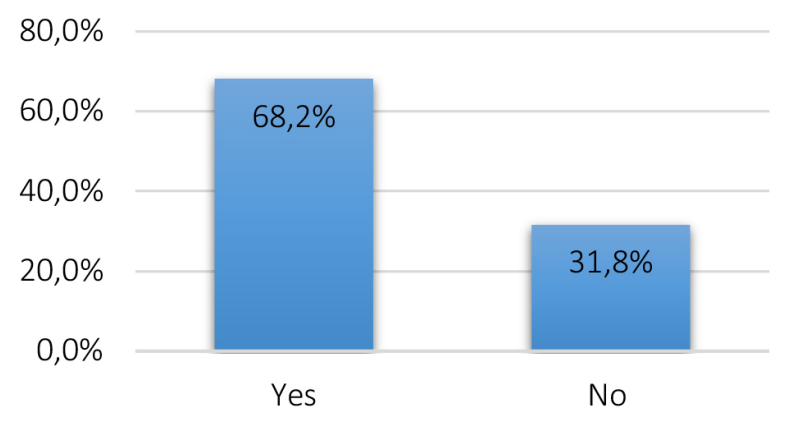

Source: Fieldwork 2020 
Figure 7: Which entity has trained your staff?

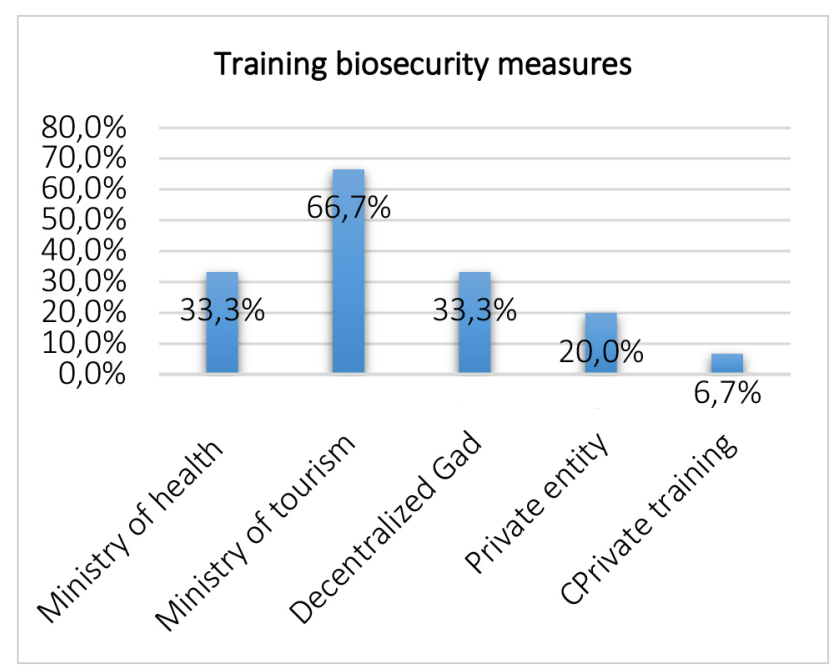

Source: Fieldwork 2020

According to the figure $\mathrm{N}^{\circ} 6,68.2 \%$ of the establishments surveyed stated that they had received training on biosecurity measures for receiving guests, while $31.8 \%$ stated that they had not received any training. In the same manner, Illustration $\mathrm{N}^{\circ} 7$ shows that the Ministry of Tourism has been one of the entities that has participated the most in these training with $66.7 \%$, followed by the Ministry of Health and the Decentralized Government with 33.3\% respectively.

According to the WHO, the lodging establishments must provide their services with the respective protection and prevention measures, which were established by the same organization (WHO, 2020). In this way, it extends the participation of both public and private entities, which must establish mechanisms, as well as coordinate and plan the necessary measures for a positive response to the health crisis (WHO, 2020).
Figure 8: Have you received assistance from governmental entities to promote / or return to operation in your establishment after Covid 19 pandemic economic recovery?

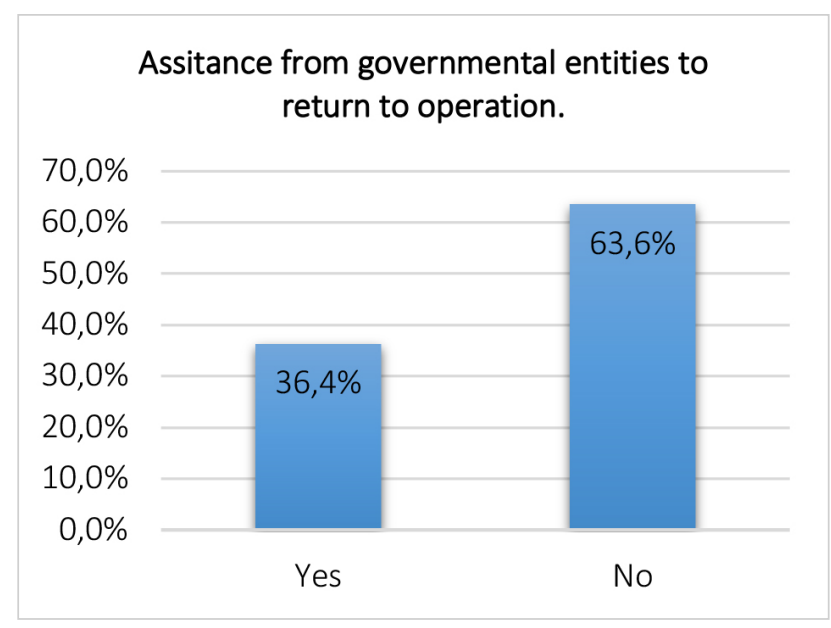

Source: Fieldwork 2020

A total of $36.4 \%$ of the establishments surveyed stated that they had received assistance from governmental entities for the economic reactivation in the face of the COVID-19 global health emergency, while $63.6 \%$ had not received any assistance.

Mintur, as the regulatory agency for tourism in Ecuador, has designed promotional activities as well as strategies for economic reactivation in the face of the health crisis. All of this includes the participation of both national and international institutions (Mintur, 2020). For this reason, public, private, national, and international entities must get involved in the reactivation of the different tourism activities. In this context, it is worrying because a higher percentage of the establishments have not received the necessary assistance, which is a government duty, as well as the responsibility to optimize the operation of tourism activities based on the needs of the customer (Pineda, Sojos, \& Calle, 2019). 
Figure 9: What losses has your establishment faced in this sanitary crisis?

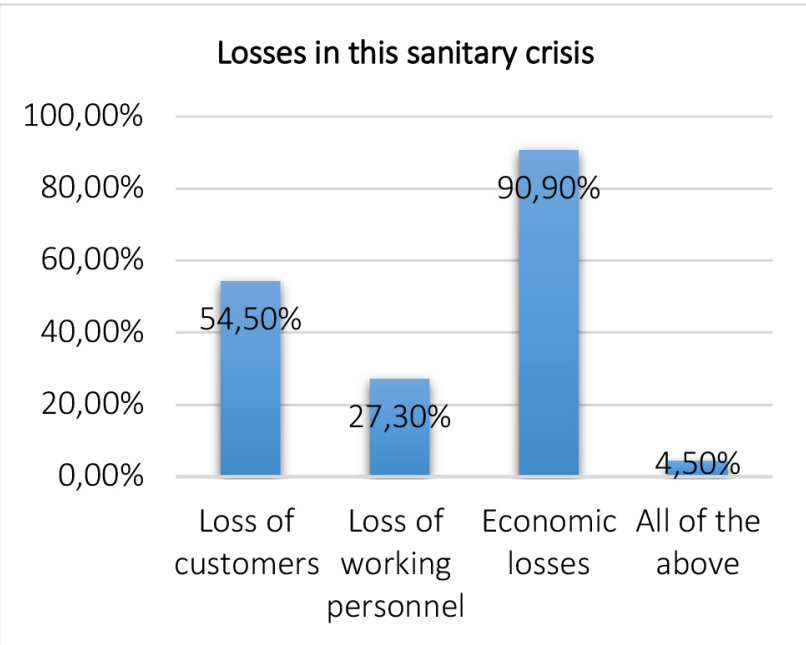

Source: Fieldwork 2020

It is evident that $90.9 \%$ of the establishments faced economic losses, followed by $54.5 \%$ which loss customers, $27.3 \%$ that loss working personnel, and $4.5 \%$ reported all of the above-mentioned losses.

The World Tourism Organization through different announcements extends its objectives focused on planning sustainability programs, in order to continue working in different tourism establishments for a long term. All through policies that are adapted to the needs that the tourism sector is going through (Félix \& Garcia, 2020).

Therefore, entities must carry out activities, which promote sustainable development; in order to counteract the negative impact or losses caused by this health crisis. In addition, Machala city has a superstructure, which allows optimizing resources, generate local regulations through municipal ordinances to strengthen the sector, and thus, increase the local development.
Figure 10: What strategies are you currently using to promote the economic development in your establishment?

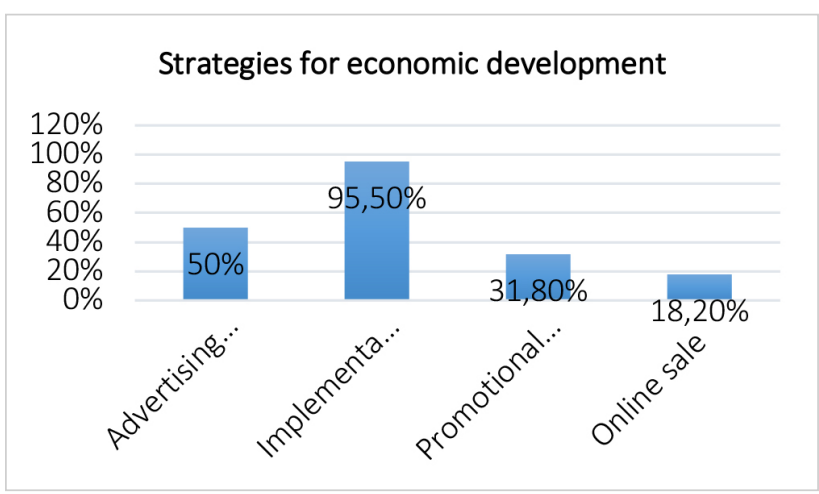

Source: Fieldwork 2020

95.5\% of hotel establishments have implemented biosecurity measures as a strategy for economic promotion, followed by advertising and marketing through different digital platforms (50\%), promotional package offers (31.8\%), and online sales (18.2\%).

Oraz \& Moral (2016) state that the vast majority of developing countries are involved in the provision of different tourism activities, covering their basic needs. In this manner, tourism contributes to sustainable development in a community, offering a better quality of life. On the other hand, the implementation of strategies will allow moderating the negative impact of this crisis, some of them are lower prices of some services, promotion on different digital platforms, online sales, etc. (Pinzón, Quevedo, Váquez, \& Quevedo, 2020).

\section{DISCUSSION}

According to Martínez (2020) in his article on tourism after Covid 19, the pandemic caused by the health emergency has had a notable effect on consumer behavior within the tourism sector. Hence, many of the lodging establishments 
have ended their commercial activities, causing negative economic, social, and tourism impacts. It occurs due to the fear of contagion that exists among the population, which limits the mobilization from one place to another and even more to travel to a destination, where people make use of different services of the tourist plant, such as lodging establishments. Therefore, there is great concern within this sector, considering that the tourist demand in a destination is fundamental for the continuity of hotel activities. Thus, the hotels in Machala city have designed strategies to promote the implementation of digital marketing, as well as innovation in customer service and service delivery with the implementation of biosafety standards and social distancing, in order to strengthen local economic development.

In the same way, the regulatory entities of the lodging sector at the national level seek to maintain the safety and hygiene of the establishments. That is why they employ licenses and registrations that guarantee the wellness of the guests. As Loor, Alodia \& Pérez (2018) state in their article on tourism activity in Ecuador, the annual operating license is a prerequisite to perform this activity and is mandatory in all hotel companies where people must follow the requirements established by the Ministry of Tourism.

On the other hand, Marmolejo (2016) expresses that the influx of tourists benefits all sectors that implicate sustainable development in a destination by making proper use of different areas of that place. That is why, in Machala city, hotel establishments have a minimal demand of guests due to the pandemic produced by Covid 19. Therefore, entrepreneurs are committed to the sector by seeking the implementation of measures and strategies that contribute positively to this activity.

According to Ruiz (2020) in his article on the evolution of the Coronavirus disease, biosecurity measures are fundamental for all commercial sectors and the population in general; due to their fundamental objective, which is to guarantee the health status of each individual. Thus, biosecurity measures such as the use of protective equipment, signage of risk areas or preventive signs, personal and establishment hygiene will ensure the safety and health of guests effectively. As a result, they can continue using these establishments and contributing to the economic development of a destination.

Hence, in order to avoid economic losses due to the lack of tourists, it is necessary that the governmental entities in competition with the tourist activity, participate in the economic reactivation of the country. As Aguirre \& Ahearn (2007) state, it is essential to design projects that minimize the effects of certain losses, which must be developed by the agents involved in the tourism sector. Furthermore, Felix \& Rivera (2018) indicate that the management of the parts involved must play a role in safeguarding and obtaining favourable responses for the risk sector.

Based on that, the implementation of new strategies aimed at overcoming the health crisis is based on counteracting the socioeconomic losses in the future. Marketing and advertising published in different digital platforms have been one of the most effective strategies when people offer the services of the hotel sector, taking into account the biosecurity measures they employ. Hence, Perdigón, Viltres \& Rosa (2018) state that the digital marketing is a negotiation method that allows and motivates consumers to acquire products or services. As a result, it generates great economic benefits for companies in crisis.

\section{CONCLUSION}

The effects caused by the sanitary emergency in hotel establishments belonging to the tourism sector have brought significant changes in the operation, including the organizational structure and the strategies that promote the economic development of the establishments. Therefore, based on this study, it was possible to identify the crisis generated by the pandemic in the hotels of Machala city. Some of the negative impacts include the economic development of the hotel sector and its influence on service providers who have been forced to implement measures or strategies that ensure the economic strengthening of each establishment and counteract some of the effects generated by the pandemic.

In this manner, the study allowed us to know the current reality of the different hotel establishments in Machala City, through the application of surveys. It evidences the biosecurity measures implemented by service providers to ensure the safety of guests and safeguard the health of people.

On the other hand, tourism activity nationally has decreased by a large percentage, causing a low demand for tourists and reducing the number of guests in hotels. Therefore, it had caused economic losses and a decrease in sources of employment. Thus, due to the effects caused by the covid 19 pandemic in the hotel sector, the active 
and continuous participation of different tourism service providers, governmental entities, and the community is fundamental to reactivate and contribute to this sector, which complements the tourism industry for its economic, social and tourism development of a destination.

\section{REFERENCES}

Acosta, A. (2020). El coronavirus en el tiempo de Ecuador. Analisis Carolina(ISSN: 2695-4362). Obtenido de https://www.fundacioncarolina.es/wp-content/uploads/2020/04/AC-23.-2020.pdf

Aguirre, J. A., \& Ahearn, M. (2007). Tourism, volcanic eruptions, and information: lessons for crisis management in National Parks, Costa Rica, 2006. Pasos, 5(2), 175-191.

Alvarado, R., \& Arévalo, I. (2020). Posibles medidas de política económica en el contexto actual y post Covid-19: Caso Ecuador. Sur Academia, 14(ISSN: 1390-9045). Obtenido de https://revistas.unl.edu. ec/index.php/suracademia/article/view/727

Calle, M., Lazo, A., \& Granados, M. (2018). Gestión del sector alojamiento-Hotel. Machala: UTMACH.

Cifuentes , J. (2020). Crisis del coronavirus: impacto y medidas económicas en Europa y en el mundo. Espacio y economia. doi:https://doi.org/10.4000/ espacoeconomia. 12874

Félix Mendoza, Á. G., \& Rivera Mateos, M. (2018). La reconstrucción de destinos turísticos degradados en América Latina. Realidades y necesidades en materia de planificación turística y cooperación entre actores en la provincia de Manabí (Ecuador). En F. Cebrián Abellán, F. J. Jover Martí, \& R. C. Lois González, América Latina en las últimas décadas: procesos y retos (págs. 11391154). Madrid: Universidad de Castilla-La Mancha.

Félix, A., \& Garcia, N. (2020). Estudio de pérdidas y estrategias de reactivación para el sector turístico por crisis sanitaria COVID-19 en el destino Manta-Ecuador. Revista internacional de turismo, empresa y territorio, 79-103. doi:10.21071/riturem.v4i1.12743

Gonzales , A. (2020). Evaluación del nivel de conocimiento sobre los protocolos de bioseguridad en el personal de los establecimientos de alojamiento. Revista investigación y desarrollo, 13(ISSN: 2361-2557). Obtenido de https://revistas.uta.edu.ec/erevista/ index.php/dide/article/download/1004/929/

Huilcapi Masacón, N. Ú., Troya Terranova, K. T., \& Ocampo Ulloa, W. L. (2020). Impacto del COVID-19 en la planeación estratégica de las pymes ecuatorianas. RECIMUNDO, 76-85. doi:10.26820/recimundo/4.(3). julio.2020.76-85

Izquierdo, R., Andrade, A., \& Lazo, A. (2018). La calidad hotelera. Revista científica de la universidad de cienfuegos, Vol 10(ISSN: 2218-3620). Obtenido de http://scielo.sld.cu/pdf/rus/v10n2/2218-3620rus-10-02-328.pdf

Lambogglia, C. (2016). Análisis del turismo y su importancia en el crecimiento económico en América Latina: En el caso del Ecuador. Obtenido de https://repositorio.flacsoandes.edu.ec/bitstream/10469/7460/2/TFLACSO-2014JCLO.pdf

Loor , L., Alodia, A., \& Peréz , M. (2018). La actividad turística en el Ecuador. Revista ECA sinergia. doi:Doi: https://doi.org/10.33936/eca_sinergia.v9i1.1195

Luzuriaga, P. (2020). Reactivación vs turistificación: los retos de las ciudades frente al turismo post pandemia. INNOVA Research Journal, Vol 5(ISSN: 24779024). Obtenido de https://revistas.uide.edu.ec/ index.php/innova/article/view/1564/1798

Marmolejo, J. (2016). Análisis de la demanda en un destino turístico singular. Cuadernos geográficos(ISSN: 0210-5462). Obtenido de https://www.redalyc. org/pdf/171/17149048013.pdf

Martínez, A. (2020). Turismo después del Covid 19. Revista Desarrollo, economia y sociedad(ISSN: 23228040), 7. Obtenido de https://www.jdc.edu.co/revistas/index.php/deyso/article/view/656

Menchero, M. (2020). Flujos turísticos y COVID-19. Revista de estudios sobre espacio y poder, Vol 11(ISSN: 2172-3958), 106. Obtenido de https://revistas.ucm.es/index.php/GEOP/article/ view/69249/4564456553386

Ministerio de Turismo. (2020). Catastro turístico nacio- 
nal. Quito. Obtenido de https://servicios.turismo. gob.ec/portfolio/catastro-turistico-nacional

Ministerio de turismo. (2020). Promedio de llegada de visitantes en el año 2019. Quito. Obtenido de https://www.turismo.gob.ec/promedio-de-Ilegada-de-visitantes-extranjeros-a-ecuador-crecio-4-en-2019/\#: :text=4\%25\%20 en\%20 2019-,Promedio\%20de\%20llegada\%20de\%20 visitantes\%20extranjeros\%20a\%20Ecuador\%20 creci\%C3\%B3\%204,Migraci\%C3\%B3n\%20del\%20 Ministerio\%20de\%2

Mintur. (2016 de febrero de 2016). Ministerio de Turismo del Ecuador. Obtenido de https://www.turismo. gob.ec/wp-content/uploads/2016/06/REGLAMENTO-DE-ALOJAMIENTO-TURISTICO.pdf

Mintur. (8 de mayo de 2020). Ministerio de Turismo. Obtenido de https://www.turismo.gob.ec/campanas-de-promocion-mecanismo-clave-para-reactivar-el-turismo/

MINTUR. (2020). Protocolo para establecimientos de alojamiento turístico. Quito. Obtenido de https://www. turismo.gob.ec/wp-content/uploads/2020/03/ protocolo_covid-19_alojamientos-turisticos.pdf

Mintur. (2020). Protocolos para prevenir posibles contagios de Covid-19. Quito. Obtenido de https:// www.turismo.gob.ec/el-ministerio-de-turismo-socializo-protocolos-para-prevenir-posibles-contagios-de-covid-19/

OMS. (25 de agosto de 2020). Organización Mundial de la Salud. Obtenido de https://apps.who.int/iris/ bitstream/handle/10665/334128/WHO-2019nCoV-Hotels-2020.3-spa.pdf

OMS. (14 de abril de 2020). Organización Mundial de la Salud. Obtenido de https://www.who.int/docs/ default-source/coronaviruse/covid-strategy-update-14april2020_es.pdf?sfvrsn=86c0929d_10

OMT. (2016). Panorama OMT del turismo internacional. Obtenido de https://www.e-unwto.org/doi/ pdf/10.18111/9789284416875

Oraz Agüera, F., \& Moral Cuadra, S. (2016). El turismo como motor potencial para el desarrollo económico de zonas fronterizas en vías de desarrollo. Un estudio de caso. EL periplo sustentable, 31(ISSN 1870-9036). Obtenido de https://rperiplo.uaemex. $\mathrm{mx} /$ article/view/4889/3408

Organización Mundial del Turismo. (2020). La Covid-19y la transformación del turismo. Obtenido de https:// www.un.org/sites/un2.un.org/files/policy_brief_ covid-19_and_transforming_tourism_spanish.pdf

Orlandini, I., Paco , P., \& Torricos , P. (2019). Crecimiento económico y la industria hotelera - Un análisis en dos ciudades patrimoniales del sur de Bolivia. Investigación \& Negocios, 12(19), 36-45.

Ortega, M. (2020). Efectos del Covid 19 en el comportamiento del consumidor. Revista de Ciencias de la Administración y Economía(ISSN: 1390-8618). Obtenido de https://retos.ups.edu.ec/index.php/ retos/article/view/20.2020.03/4145

Perdigón Llanes, R., Viltres Sala, H., \& Madrigal Leiva, I. R. (2018). Estrategias de comercio electrónico y marketing digital para pequeñas y medianas empresas. Revista Cubana de Ciencias Informáticas, 12(3), 192-208.

Pineda, A., Sojos, G., \& Calle, M. (2019). Análisis del sistema turístico de la parroquia Casacay, Pasaje, Ecuador. RiAT, 15(2), 162.169.

Pinzón , L., Quevedo, M., Váquez, L., \& Quevedo, J. (2020). Impacto del covid-19 en el emprendimiento del sector turístico en el Ecuador. Dominio de las ciencias, 13521367. doi:http://dx.doi.org/10.23857/dc.v6i3.1377

Quintana, M. (2019). La Hotelería en Quito. INNOVA Research Journal( ISSN 2477-9024). Obtenido de https://dialnet.unirioja.es/descarga/articulo/7475555.pdf

Rodriguez, D., \& Álvarez, J. (2016). Vulnerabilidad del turismo y comunicación institucional ante desastres: Estudios de casos. REDMARKA, 2(11), 137-161.

Ruiz, G. (2020). Evolución de la enfermedad por Coronavirus. La ciencia al servicio de la salud, 11(ISSN 1390-874X.). Obtenido de http://revistas.espoch. edu.ec/index.php/cssn/article/view/441 